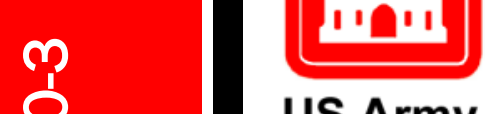

US Army Corps

of Engineers ${ }_{\circledast}$

Engineer Research and

Development Center

ERDC 6.2 Boreal Aspects of Ensured Maneuver (BAEM)

\title{
Methods for Measuring Snow Moisture and Density
}

Bruce Elder, Sally Shoop, Mary Feyrer, and Samuel Beal

July 2020 
The U.S. Army Engineer Research and Development Center (ERDC) solves the nation's toughest engineering and environmental challenges. ERDC develops innovative solutions in civil and military engineering, geospatial sciences, water resources, and environmental sciences for the Army, the Department of Defense, civilian agencies, and our nation's public good. Find out more at www.erdc.usace.army.mil.

To search for other technical reports published by ERDC, visit the ERDC online library at https://erdclibrary.on.worldcat.org/discovery 
July 2020

\section{Methods for Measuring Snow Moisture and Density}

Bruce Elder, Sally Shoop, Mary Feyrer, and Samuel Beal

U.S. Army Engineer Research and Development Center (ERDC)

Cold Regions Research and Engineering Laboratory (CRREL)

72 Lyme Road

Hanover, NH 03755-1290

Final Report

Approved for public release; distribution is unlimited.

Prepared for Assistant Secretary of the Army for Acquisition, Logistics, and Technology 103 Army Pentagon

Washington, DC 20314-1000

Under Project 465395, ERDC 6.2 "Boreal Aspects of Ensured Maneuver (BAEM)," and Project 471941, "Remote Assessment of Snow Mechanical Properties" and "Mobility in Peat and Northern Soils" 


\section{Preface}

This study was conducted for the Assistant Secretary of the Army for Acquisition, Logistics, and Technology under project number 465395 , "Boreal Aspects of Ensured Maneuver (BAEM)," which is part of the U.S. Army Engineer Research and Development Center (ERDC) 6.2 Remote Assessment of Infrastructure for Ensured Maneuver (RAFTER) Program managed by Ms. Danielle Whitlow, ERDC Geotechnical and Structures Laboratory (GSL).

The work was performed by the Terrestrial and Cryospheric Sciences Branch (CEERD-RRG), the Force Projection and Sustainment Branch (CEERD-RRH), and the Biogeochemical Sciences Branch (CEERD-RRN) of the Research and Engineering Division (CEERD-RR), U.S. Army Engineer Research and Development Center, Cold Regions Research and Engineering Laboratory (ERDC-CRREL). At the time of publication, Dr. John Weatherly was Chief, CEERD-RRG; Mr. Justin Putnam was Acting Chief, CEERD-RRH; Dr. Justin Berman was Chief, CEERD-RRN; and Mr. Jered Oren was Acting Chief, CEERD-RR. The Deputy Director of ERDCCRREL was Mr. David B. Ringelberg, and the Director was Dr. Joseph L. Corriveau.

This Miscellaneous Paper (MP) was published as the following:

Elder, E., S. Shoop, M. Feyrer, and S. Beal. 2019. "Methods for Measuring Snow Moisture and Density." In Proceedings of the 18th International Conference on Cold Regions Engineering and the $8^{\text {th }}$ Canadian Permafrost Conference, 18-22 August 2019, Quebec City, Quebec, Canada.

COL Teresa A. Schlosser was Commander of ERDC, and Dr. David W. Pittman was the Director.

DISCLAIMER: The contents of this report are not to be used for advertising, publication, or promotional purposes. Citation of trade names does not constitute an official endorsement or approval of the use of such commercial products. All product names and trademarks cited are the property of their respective owners. The findings of this report are not to be construed as an official Department of the Army position unless so designated by other authorized documents.

DESTROY THIS REPORT WHEN NO LONGER NEEDED. DO NOT RETURN IT TO THE ORIGINATOR. 


\title{
Methods for Measuring Snow Moisture and Density
}

Bruce Elder

ERDC-CRREL, Hanover, New Hampshire, USA

Sally Shoop, Ph.D.

ERDC-CRREL, Hanover, New Hampshire, USA

Mary Feyrer

ERDC-CRREL, Hanover, New Hampshire, USA

Samuel Beal

ERDC-CRREL, Hanover, New Hampshire, USA

\begin{abstract}
The manual measurement of snow density through sample collection and liquid water content by calorimetry can be cumbersome and time consuming, while electronic methods are considerably faster. Field and laboratory experiments were conducted to compare several techniques for measuring snow density and moisture content. Two methods for the measurement of snow moisture were used in both field and laboratory settings: the Denoth meter capacitance plate and the Toikka Oy "Snow Fork" microwave resonance technique. Snow density was measured using three techniques: a direct sample measurement (rectangular snow scoop); snow fork; and, in the lab setting, the Bruker Sky-Scan 1173 Micro CT - X-ray scanner using image analysis techniques.

Results show that the snow fork densities are generally reliable in dry snow but become inaccurate (low) in wet snow. Density from direct sampling was on average $0.037 \mathrm{~g} / \mathrm{cc}$ greater than the snow fork density. Densities measured by the Micro-CT were inaccurate once the snow began to melt, primarily due to sample collection and processing technique. For moisture measurements, we found the Snow Fork to be a reliable tool for measuring the moisture content and density of snow. The Denoth moisture values are on average $0.054 \%$ by volume higher than the snow fork moisture. All Denoths tested, report similar moisture values, which was encouraging as these devices are over 20 years old and there is no other source for calibration.
\end{abstract}

KEY WORDS: Density, Moisture, Snow. 
OBJECTIVES

The objectives of this work were two fold (1) determine the accuracy and reliability of the Toikka Snow fork by comparing the density and moisture data it collects to moisture data from Denoth meters and directly sampled snow densities, and (2) compare different Denoth meters used by CRREL in order to ensure that they are producing similar results.

\section{EXPERIMENTAL PROGRAM}

\subsection{Instrument Descriptions}

The Denoth snow moisture meter is an electronic device that measures the real part of the dielectric constant of snow at $20 \mathrm{MHz}$ Empirical relationships with snow moisture and density allow the calculation of snow volume wetness (Denoth, 1989). Density must be measured separately for input into the equation. This was done using a $100 \mathrm{~cm}^{3}$ rectangular box cutter, and weighing the sample on a digital scale. These measurements were taken in the side wall of the snow block, Figure 2 and 3 CRREL has five Denoth meters in its inventory. In the laboratory setting, each was used to check their current accuracy and calibration with each other? Two Denoth meters were available for use in the field. One belonging to CRREL, and a second belonging to another agency. Measurements within $5 \mathrm{~cm}$ of the ground are affected by the dielectric properties of the underlying surface and should be interpreted with caution.

The "Snow Fork" manufactured by TOIKKAoy measures the real and imaginary components of the dielectric constant of snow using microwave resonance in the range of 500 to $900 \mathrm{MHz}$ The dielectric constant can be related to snow density and liquid water content through semi-empirical relationships (Tiuri and Sihvola, 1986). Here, the snow fork was used to measure density and liquid water content (wetness). This was done by installing the snow fork into the snow block at the beginning of the experiment and autonomously recording the data for the duration of the experiment, Figures 3 and 4 . In the field measurements were taken every $5 \mathrm{~cm}$ of depth. Similar to the Denoth Meter, observations within $5 \mathrm{~cm}$ of the ground should be interpreted with caution.

Micro CT scan, or Computer Tomography was performed on three occasions during the laboratory tests, at the start of experiment, two hour and five hours elapsed time into the experiment. Samples were removed from the snow block and measured with the Bruker Skyscan $1173 \mu \mathrm{CT}$ scanner. The micro-CT scanner is housed in a $-10 \mathrm{oC}$ freezer to prevent additional melting of the samples during measurement. The scans were measured with $40 \mathrm{kV}$ X-rays at $200 \mathrm{~mA}$ and the nominal resolution was $15-20 \mu \mathrm{m}$. This instrument produces a three-dimensional (3-D) representation of the snow from which density, grain size and other statistical measurements. 


\subsection{Laboratory experimental design}

A snow sample was constructed in an insulated box approximately $0.9 \mathrm{~m} \times 0.6 \mathrm{~m}$, filled to a depth of $0.25 \mathrm{~m}$ with manufactured snow, Figure 3 . To do this the snow was sieved so that it was uniform and allowed to sit for more than 24 hours so the snow would settle and sinter similar to a natural snow pack. A string of five temperature sensors was inserted vertically into the snow at the corner of the box. The day of testing, the box was placed outside it in a shaded location. The snow fork was inserted into a hole in the side of the box $10 \mathrm{~cm}$ above the bottom of the box. A white cloth was placed over the snow fork to prevent it from self-heating and thus affecting the measurement.

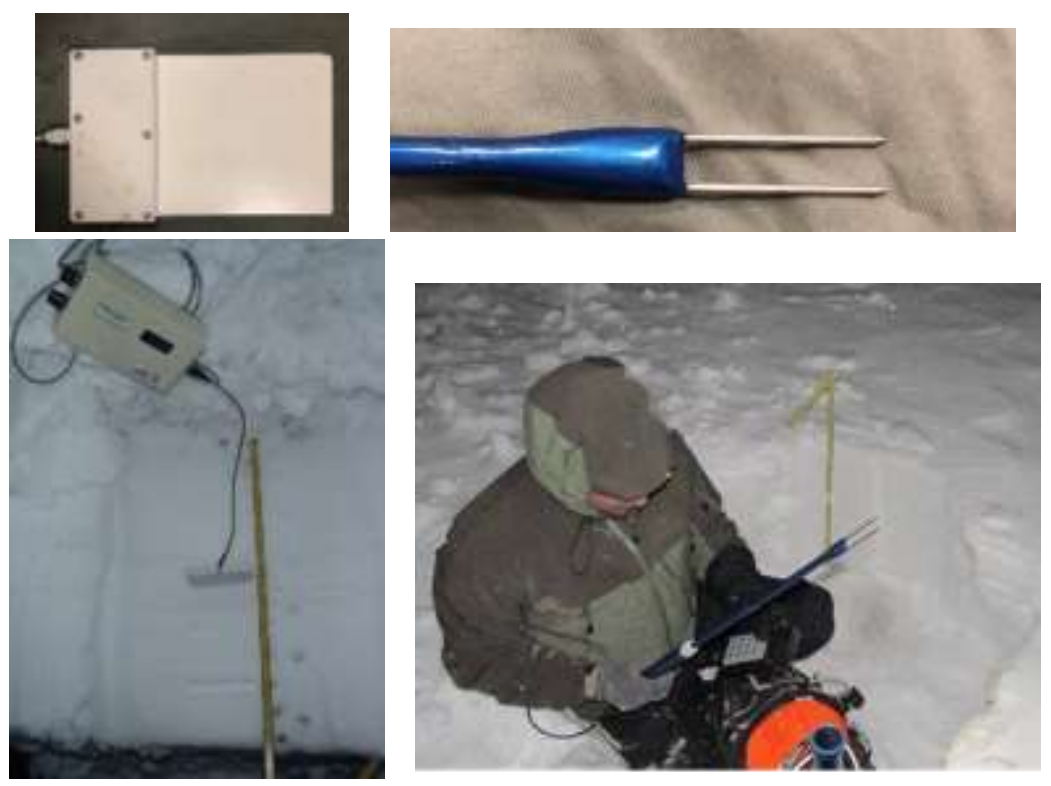

Figure 1. Denoth meter (left) and Snow Fork (right) alone and taking field measurements.
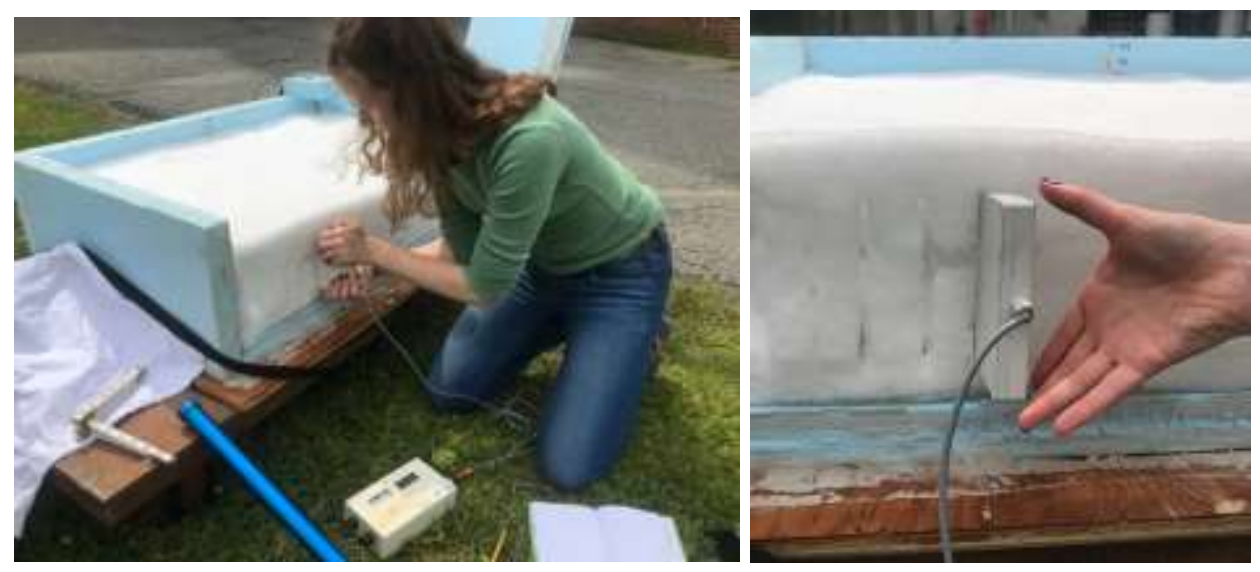

Figure 2. Inserting the Denoth meters into the side of the snow vertically. 


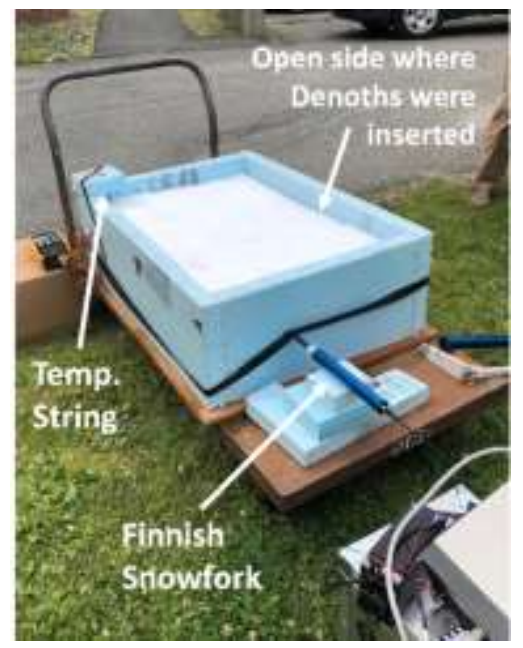

Figure 3. Inserting the Denoth meters into the side of the snow vertically.

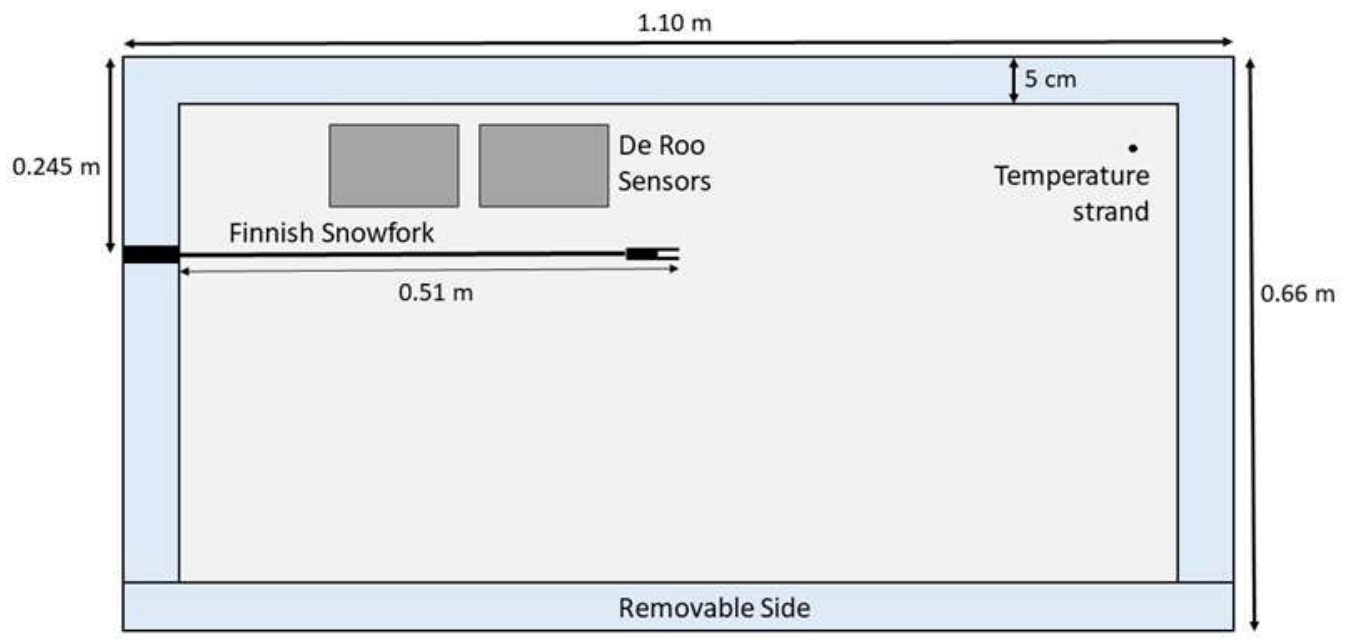

Figure 4. Placement of instrumentation within the snow box.

The snow fork recorded data automatically every 15 minutes. In addition we recorded the Denoth meter readings, snow density and temperature manually every half an hour for the first 2.5 hours of the experiment and then 3.5 hours and 5.5 hours of the experiment.

Temperature was measured in two ways. The installed temperature string melted out prematurely due to snow melting out around the wires, thus we switched to using a digital read-out temperature probe.

Density measurements were taken every time we took the Denoth meter and temperature measurements. We obtained density measurements using a stainless steel box cutter with a height of $3 \mathrm{~cm}$ and a volume of $100 \mathrm{~cm}^{3}$ and weighing the resulting snow sample. On three occasions we removed samples for CT scanning by taking a small cylindrical vial 
and pushing it into the snow. By measuring and weighing the samples a bulk density value was obtained.

\subsection{Field measurements}

The snow fork and Denoth meters were also compared during two field campaigns. The first testing was in January 2018, in West Yellowstone, Montana at the Nevada Automotive Test Center's (NATC) Winter Test Facility. A second set of field data was obtained in February 2018 in Calumet, Michigan at the Keweenaw Research Center (KRC) a research agency of Michigan Technological University. Both of these facilities boast miles of consistently groomed surfaces for vehicle testing, as well as areas of naturally fallen snow.

Groomed surfaces were often too hard or too thin to insert the instruments. They were mainly used in the virgin snow pack. The snow fork was inserted horizontal into the face of the wall of a snow pit every $5 \mathrm{~cm}$ with depth. The Denoth meter plate was placed on the surface of the snow for a $1 / 2$ plane reading, and also inserted horizontally into the snow pit for measurements every $10 \mathrm{~cm}$ with depth. Figure 1.

\section{RESULTS}

Figure 5 shows the density data collected by the snow fork, micro-CT scans, and from snow samples during the lab experiment. The measurements did not measure the same exact snow sample. For density, the box cutter samples were taken along the edge of the box where there may be been differential melting due to edge affects. The snow fork, however was on the interior of the block of snow - and measuring the same area of snow - thus is it more consistent between readings. The snow fork has an upper limit of $10 \%$ moisture content above which all data was removed from the plot.

Liquid moisture content in the snow is plotted in the Figure 6. All methods and measurements track each other well. The spike in snow fork moisture at the four hour mark of the experiment is outside of the range of the instrument. This is thought to be when the pool of water that accumulated on the bottom of the sample container was at its maximum, and just before it drained away (visual evidence)

Sample images from the micro-CT are seen in Figure 7. You can see the snow grains (white), and the pore space (black). This is a good visual representation of how the snow pores fill in with melt water as the pack is warming. 


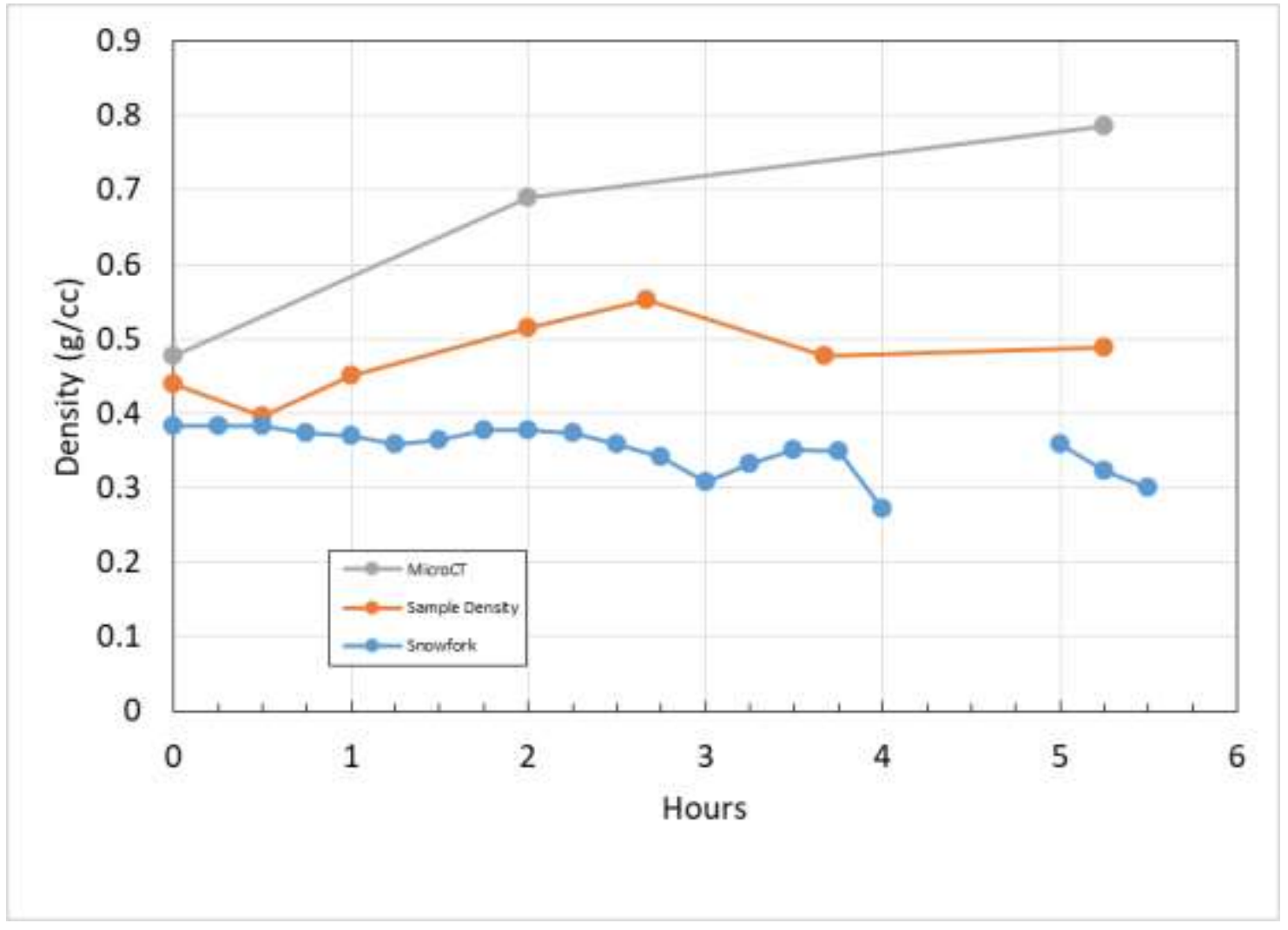

Figure 5. Time series of density measured by the snow fork, box sampler, and micro-CT.

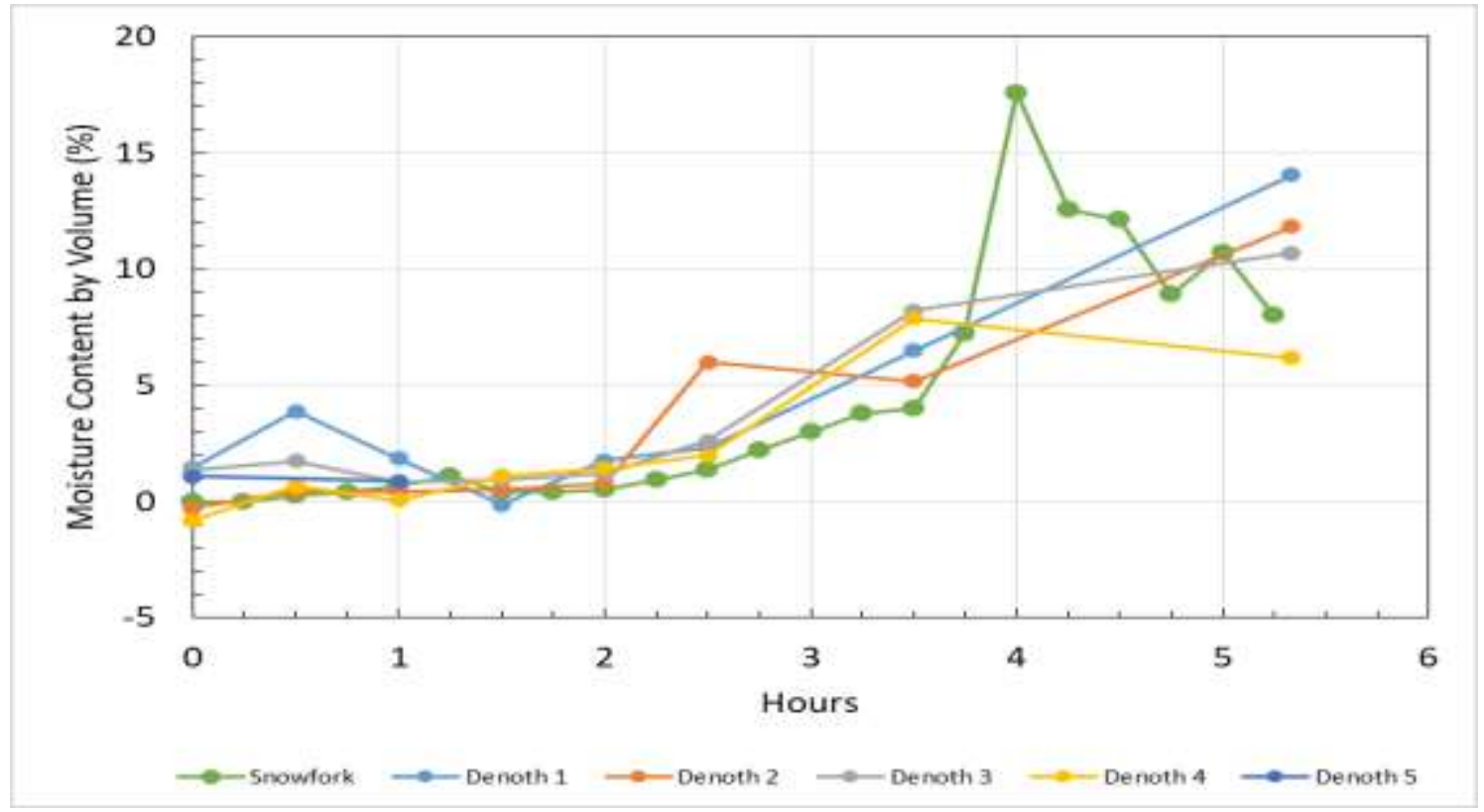

Figure 6. Comparison of moisture contents measured by the snow fork and five denoth meters. 

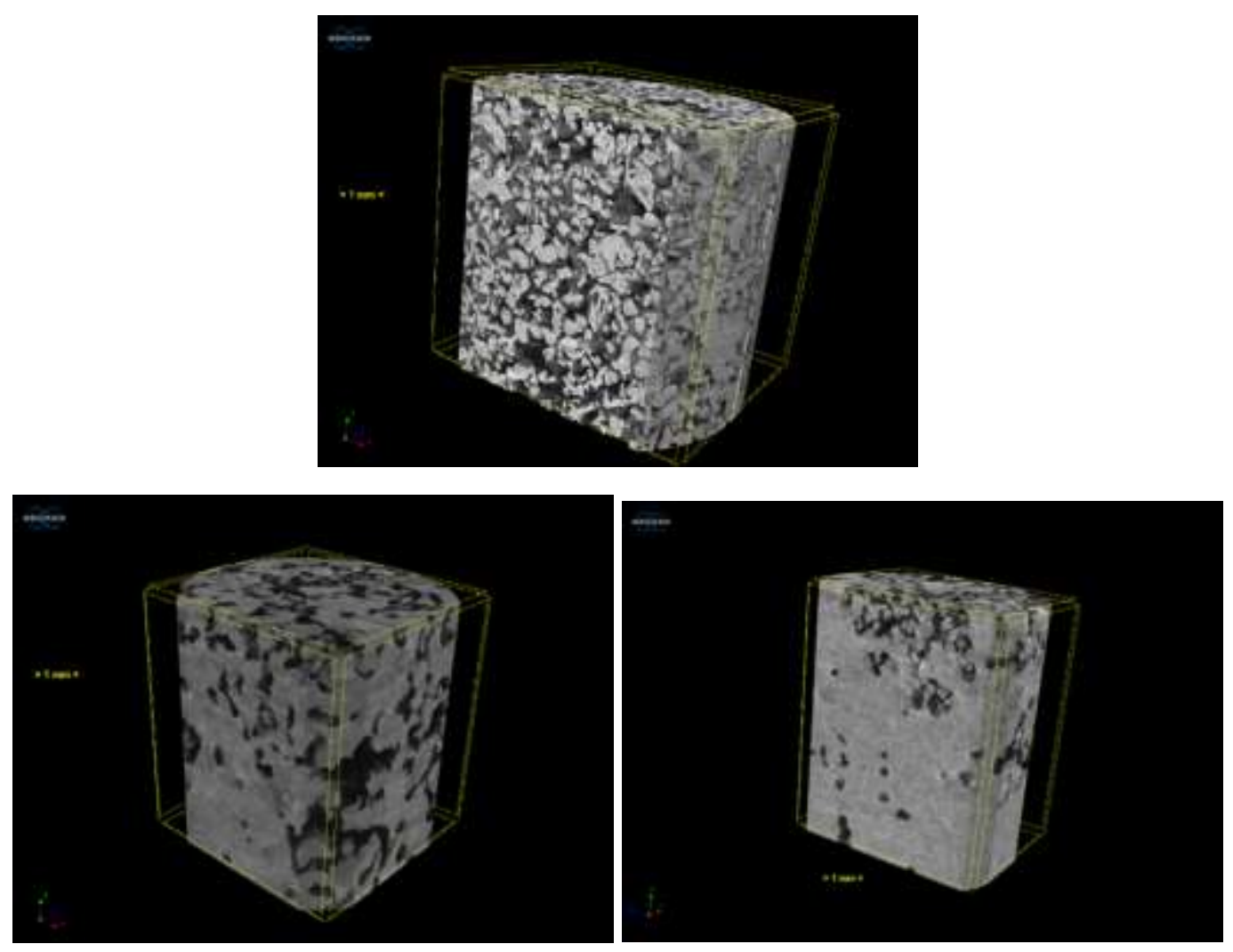

Figure 7. Images from the CT scanner, initial conditions (top) through final measurement (bottom right).

Both the Denoth and the snow fork methods were used in field testing in Montana and Michigan in early 2018. Figure 9 shows plots of snow densities, temperature profiles and moisture content from 2 snow pits at KRC on 19 February 2018. The pits were in undisturbed snow, near to each other but in different conditions. The first was on an old flat roadway while the second was in the edge of the woods. Snow density measurements were made by both direct volume sampling (green), and with the Finnish Fork (blue). Black, dotted line in plots represents the calculated average between these measurements, with a shaded area in between. Temperature measurements were made with a handheld type-T thermocouple. Dashed lines and shaded area (pink) represent a \pm 1.0 degree standard error (typical for a type-T thermocouple). Black diamond shows air temperature as measured $3 \mathrm{~cm}$ above the ground. Snow moisture measurements were made using two Denoth sensors. The results were averaged and are shown as a black, dotted line, with a shaded are in between. 

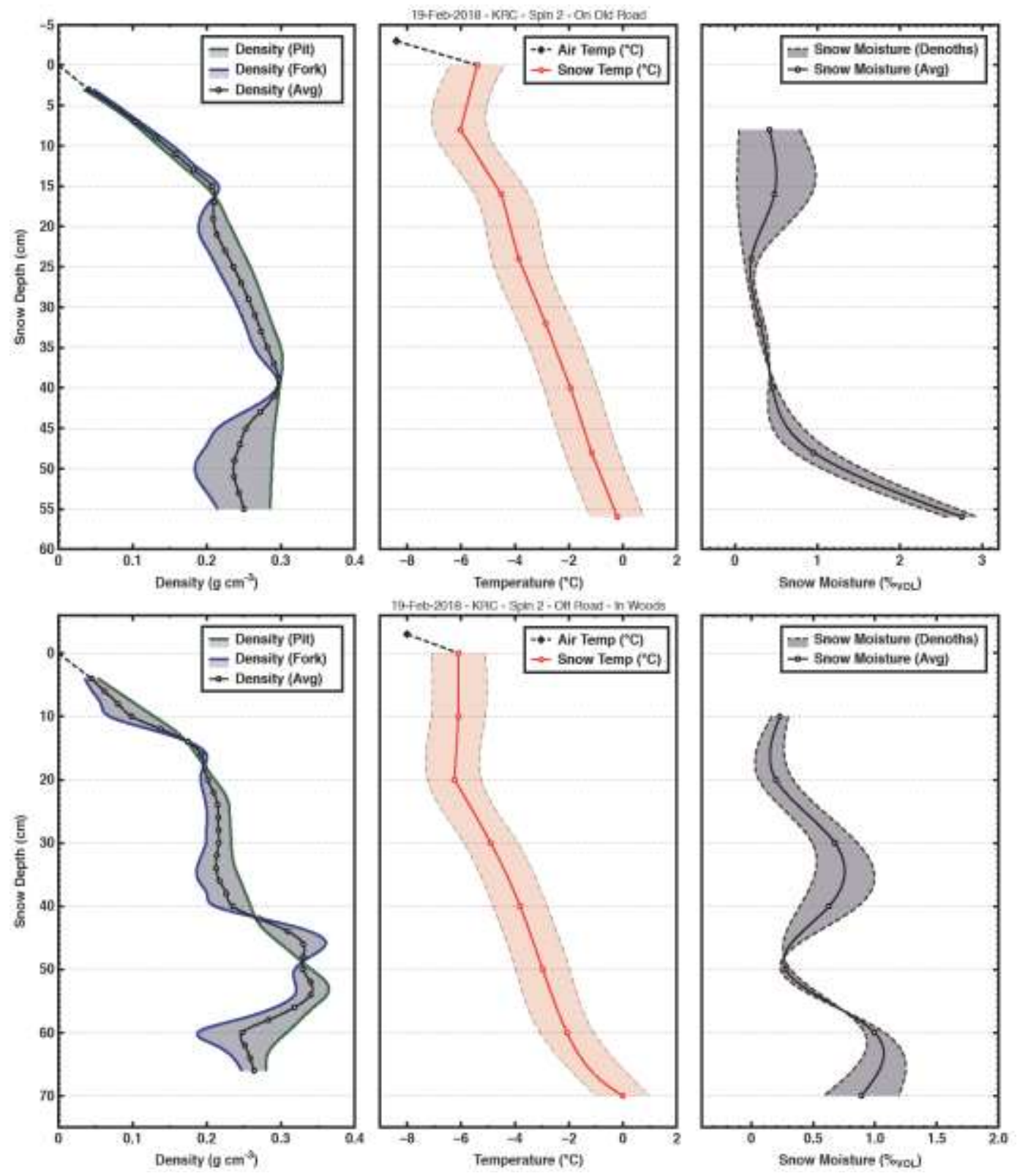

Figure 8. Snow pit density, temperature and snow moisture profiles for KRC as recorded for 19-Feb through 23-Feb, 2018.

Comparison of data from all sites samples at the 2 field sites was performed. Figure 9. At both of the field sites, the snow pack was cold and dry, with moistures less than $1.5 \%$. Density and moisture readings were averaged throughout the snow pack for statistical analysis between sampling sites. Due to all samples having a really low moisture content, this resulted in the conclusion that the sample density and snow fork densities were not statistically equivalent (T-Test, $p=0.00043$ ) and that the sample density is on average $0.037 \mathrm{~g} / \mathrm{cm}^{3}$ greater than the snow fork density. Moisture measurements also were not statistically equivalent (Wilcoxon rank test, $p=0.001$ ). This may be due to the errors associated with measuring a separate snow density, which is slightly at a different 
location to avoid sample contamination. With low moisture and measurement errors, the moisture would return a value that is less than zero which is not possible. If these negative numbers are rounded up to zero, the Denoth moisture values are on average $0.054 \%$ by volume higher than the snow fork moisture, and $0.24 \%$ by volume higher when negative moisture values are rounded to 0 . Field measurements taken using two Denoth meters in the field (noted as Sally's and Russ's in Figure 8) resulted in them being statistically equivalent (Wilcoxon rank test, $p=0.73$ ) and thus interchangeable.

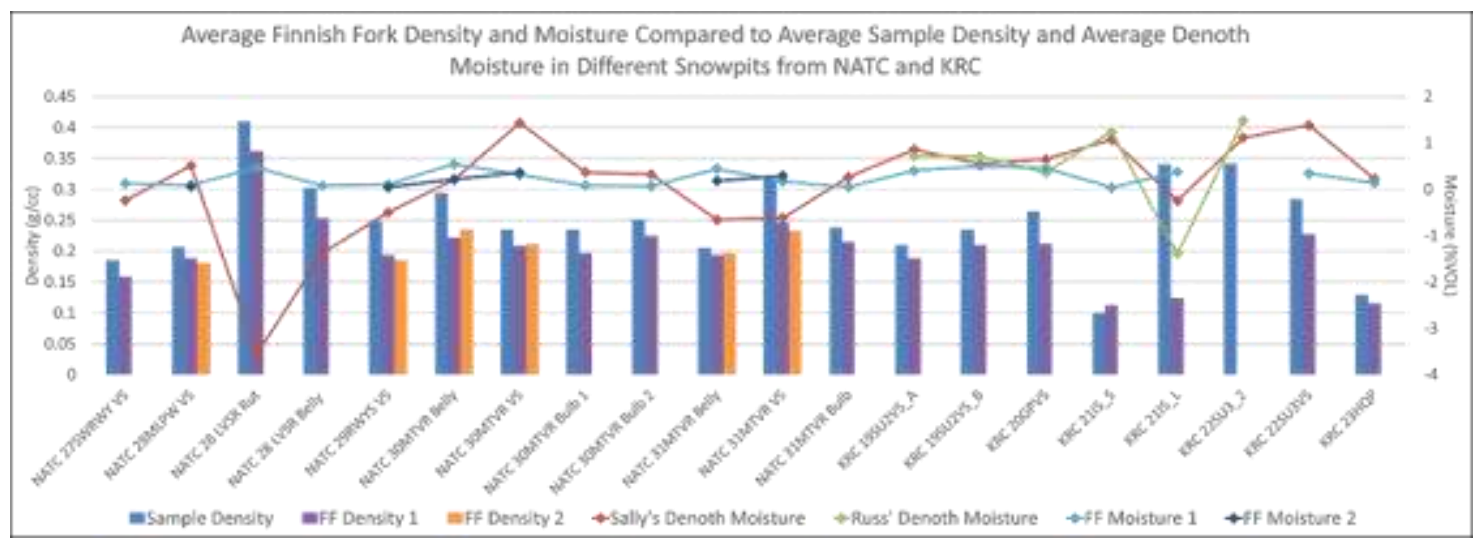

Figure 9. Field data of average snow density and moisture at various sites.

\section{CONCLUSIONS}

The Toikka snow fork and Denoth meter are both viable instruments for measuring snow moisture. In our studies, the snow fork recorded both slightly lower density and moisture values but was within acceptable range of variability for the snow conditions that were encountered. Use of the Denoth meters, is time consuming as manually measured snow density measurements must be performed, whereas the snow fork measures both density and moisture thus allowing for more measurements to be taken in an allotted time. Both methods tracked well in both field and lab experiments and all five of CRREL's 20+ year old Denoth meters were still within tolerances of the values presented and compared well with the newer technology snow fork.

\section{ACKNOWLEDGEMENTS}

Funding for this project was provided by the Assistant Secretary of the Army for Acquisition, Logistics, and Technology under project number 465395, "Boreal Aspects of Ensured Maneuver (BAEM)," which is part of the U.S. Army Engineer Research and Development Center (ERDC) 6.2 Remote Assessment of Infrastructure for Ensured Maneuver (RAFTER) Program managed by Ms. Danielle Whitlow. This work is continuing under project number 471941 "Remote Assessment of Snow Mechanical Properties," under the Entry and Sustainment in Complex Contested Environments Program managed by Dr. John Rushing. Many others helped with the testing and data 
reduction and analysis for this work including Lauren Farnsworth, John Fegyveresi, Ross Lieblappen and Zoe Courville of ERDC-CRREL. ERDC-CRREL gratefully acknowledges the cooperation of the staff at both NATC and KRC.

\section{REFERENCES}

Carroll, T. (1977). A Comparison of the CRREL $500 \mathrm{~cm}^{3}$ Tube and the ILTS 200 and 100 $\mathrm{cm}^{3}$ Box Cutters used for Determining Snow Densities. Journal of Glaciology. 18(79): $334-337$.

Conger, S. M. and McClung, D.M. (2009). Comparison of Density Cutters for Snow Profile Observations. Journal of Glaciology, 55(189): 163 - 169.

Conover, W. J., and Iman, R.L.. (1979). On Multiple-Comparisons Procedures. LA-7677MS. Los Alamos, NM: Los Alamos Scientific Laboratory.

Denoth, A. (1989). Snow Dielectric Measurements. Advances in Space Research, 9(1): 233-243.

Marshall, H.-P., Schneebeli, M. and Koh, G., 2007. Snow stratigraphy measurements with high-frequency FMCW radar: Comparison with snow micro-penetrometer. Cold

Regions Science and Technology, 47(1-2): 108-117.doi: doi:10.1016/j.coldregions.2006.08.008

R Core Team. (2017). R: A Language and Environment for Statistical Computing. Vienna, Austria: R Foundation for Statistical Computing. https://www.R-project.org/.

Tiuri, M. and A. Sihvola (1986) Snow fork for field determination of the density and wetness profiles of a snow pack. Hydrologic Applications of Space Technology (Proceedings of the Cocoa Beach Workshop, Florida, August 1985), IAHS Publ. no. 160. 


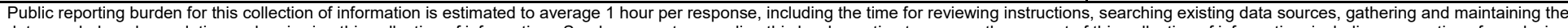

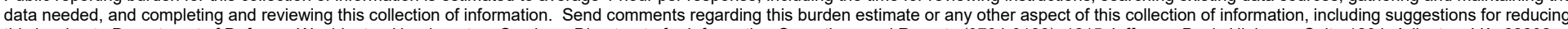

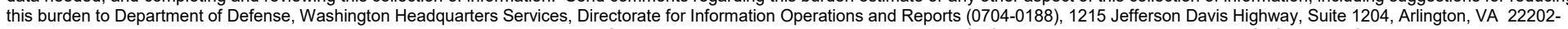

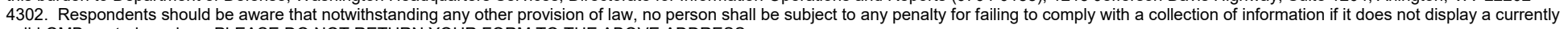
valid OMB control number. PLEASE DO NOT RETURN YOUR FORM TO THE ABOVE ADDRESS.
1. REPORT DATE (DD-MM-YYYY)
2. REPORT TYPE
3. DATES COVERED (From - To)

July 2020

4. TITLE AND SUBTITLE

Final

5a. CONTRACT NUMBER

Methods for Measuring Snow Moisture and Density

5b. GRANT NUMBER

5c. PROGRAM ELEMENT NUMBER

6. AUTHOR(S)

Bruce Elder, Sally Shoop, Mary Feyrer, and Samuel Beal

5d. PROJECT NUMBER

465395

5e. TASK NUMBER

5f. WORK UNIT NUMBER

7. PERFORMING ORGANIZATION NAME(S) AND ADDRESS(ES)

Cold Regions Research Laboratory

U.S. Army Engineer Research and Development Center

72 Lyme Road

8. PERFORMING ORGANIZATION REPORT NUMBER

Hanover, NH 03755

9. SPONSORING / MONITORING AGENCY NAME(S) AND ADDRESS(ES)

ERDC/CRREL MP-20-3

Assistant Secretary of the Army (AL\&T)

103 Pentagon

Washington, DC 20314

11. SPONSOR/MONITOR'S REPORT NUMBER(S)

\section{DISTRIBUTION / AVAILABILITY STATEMENT}

Approved for public release; distribution is unlimited.

\section{SUPPLEMENTARY NOTES}

Originally published in Proceedings of the 18th International Conference on Cold Regions Engineering and the 8th Canadian Permafrost Conference, 18-22 August 2019, Quebec City, Quebec, Canada.

\section{ABSTRACT}

The manual measurement of snow density through sample collection and liquid water content by calorimetry can be cumbersome and time consuming, while electronic methods are considerably faster. Field and laboratory experiments were conducted to compare several techniques for measuring snow density and moisture content. Two methods for the measurement of snow moisture were used in both field and laboratory settings: the Denoth meter capacitance plate and the Toikka Oy "Snow Fork" microwave resonance technique. Snow density was measured using three techniques: a direct sample measurement (rectangular snow scoop); snow fork; and, in the lab setting, the Bruker Sky-Scan 1173 Micro CT - X-ray scanner using image analysis techniques.

Results show that the snow fork densities are generally reliable in dry snow but become inaccurate (low) in wet snow. Density from direct sampling was on average $0.037 \mathrm{~g} / \mathrm{cc}$ greater than the snow fork density. Densities measured by the Micro-CT were inaccurate once the snow began to melt, primarily due to sample collection and processing technique. For moisture measurements, we found the Snow Fork to be a reliable tool for measuring the moisture content and density of snow. The Denoth moisture values are on average $0.054 \%$ by volume higher than the snow fork moisture. All Denoths tested, report similar moisture values, which was encouraging as these devices are over 20 years old and there is no other source for calibration.

\section{SUBJECT TERMS}

Density, Moisture, Snow

\begin{tabular}{|c|c|c|c|c|c|}
\hline 16. SECURITY CL & IFICATION OF: & & 17. LIMITATION & 18. NUMBER & 19a. NAME OF RESPONSIBLE PERSON \\
\hline $\begin{array}{l}\text { a. REPORT } \\
\text { Unclassified }\end{array}$ & $\begin{array}{l}\text { b. ABSTRACT } \\
\text { Unclassified }\end{array}$ & $\begin{array}{l}\text { c. THIS PAGE } \\
\text { Unclassified }\end{array}$ & SAR & 13 & $\begin{array}{l}\text { 19b. TELEPHONE NUMBER } \\
\text { (include area code) }\end{array}$ \\
\hline
\end{tabular}

